\title{
Analysis of longevity traits and lifetime productivity of crossbred dairy cows in the Tropical Highlands of Ethiopia
}

\author{
Kefena Effa ${ }^{1 *}$, Diriba Hunde ${ }^{1}$, Molla Shumiye ${ }^{1}$ and Roman H. Silasie ${ }^{1}$ \\ Ethiopian Institute of Agricultural Research, Holetta Agricultural Research Center, P. O. Box 2003, Addis Ababa, \\ Ethiopia.
}

Accepted 11 November, 2013

\begin{abstract}
Longevity traits, lifetime milk and calf productivities are one of the primary interests of dairy cattle producers. We used lifetime data of 523 crossbred dairy cows that born between 1980 and 2003 in the central tropical highlands of Ethiopia with the purpose to evaluate longevity traits and associated lifetime milk and calf productivity. Based on the type of sires used and level of exotic gene inheritances, the crossbred dairy cows were classified in to six genetic groups. These include $F_{1}$ Friesian $x$ Boran $\left(F_{1}\right.$ $F x B o), F_{1}$ Jersey $x$ Boran $\left(F_{1} J x B o\right), F_{2}$ Friesian $x$ Boran $\left(F_{2} F x B o\right), F_{2}$ Jersey $x$ Boran $\left(F_{2} J x B o\right)$ and $75 \%$ Friesian and Jersey inheritances. A Generalized Linear Model in the statistical analysis system (SAS, 2004) was used to analyze the data. The overall least squares means $\pm \mathrm{s}$. e. for total life (TL), herd life $(\mathrm{HL})$, productive life (PL), lifetime milk yield (LTMY) and lifetime calf crop production were $4036 \pm 126.3$ days, $2675.74 \pm 201.7$ days, $1951.00 \pm 173.8$ days, $10460.6 \pm 1117.4 \mathrm{~L}$ and $5.70 \pm 0.2$ calves, respectively. The overall least squares means $\pm \mathrm{s}$. e. for lifetime milk yield per day of total life (LTMY/TL), lifetime milk yield per day of herd life (LTMY/HL) and lifetime milk yield per day of productive life (LTMY/PL) were $2.56 \pm 0.2,3.97 \pm 0.3$ and $5.26 \pm 0.3 \mathrm{~L}$, respectively. In conclusion, first generation crosses of all types, particularly those sired by Jersey semen were superior in all the lifetime performance traits considered in this study while second generation $\left(F_{2}\right)$ crosses were inferior in all the lifetime productivity indicators.
\end{abstract}

Key words: Herd life, lifetime milk yield, longevity, productive life.

\section{INTRODUCTION}

Longevity is one of the economically most important functional trait in dairy cattle populations. Nevertheless, the definition given to the term longevity is inconsistent in several literatures. It has been defined as the number of lactations completed (Ibeawuchi, 1984), length of productive life (Arthur et al., 1992; Enyew et al., 1999), the entire lifespan from birth until disposal from the herd (Chaudry and Shafiq, 1995) and survival to certain lactations (Brotherstone et al., 1997; Jairath et al., 1998).

For a close observer, however, the entire lifespan of dairy cows is often partitioned in to two major time periods: (i) the costly period from birth to the first calving and; (ii) the following productive period from first calving to disposal from the herd. In most literatures, the entire lifespan is defined as longevity or total life and part of lifespan from first calving to disposal from the herd is defined as herd life. Productive life is usually defined as the total number of days that dairy cows stay in milking in their entire lifespan. This lifespan classifications patterns seem more informative and therefore, used throughout this report. 
In any dairy cattle production enterprise, the lengths of life of a dairy cow have substantial impact on economic performance. Arthur et al. (1992) reported that longer lifespan in dairy cows allows producers to be more selective in choosing replacement heifers because only a few have to be chosen each year. Higher longevity also reduces the cost of herd replacements, increases the number of animals available for marketing, and increases the proportion of the high-producing, mature animals in the breeding herd (Arthur et al., 1992). Besides, longer average life will lead to a higher proportion of cows in later high-producing lactations and therefore, increase lifetime productivity of dairy cows. Renkema and Stelwagen (1979) showed that an increased length of productive life from about three to four lactations increased milk yield per lactation or profit per year by 11 to $13 \%$ and higher percentage of calf crop will born and weaned.

Research evidences (Larroque and Ducrocq, 2001; Zavadilova et al., 2009) showed that type and linearly measured body traits as well as some of the dairy characters in dairy cattle poses negative influence on the length of productive life of a cow. However, in the lowinput low-output smallholder dairy production systems of the tropics, the lifespan of dairy cows is often decided not only by cow's milk yield, but also by the owner. For instances, Rufino et al. (2009) reported that evaluation of lifetime productivity is important to target interventions for improving productivity of smallholder dairy systems in the highlands of East Africa, because cows are normally not disposed off based on productive reasons, rather it is determined by feeding strategies and involuntary culling. In such systems, voluntary culling of dairy cows is rarely practiced because farmers that have few animals face difficulties to spread risk. Kebreab et al. (2005) also showed that lifetime productivity needs to be maximized to favor longer stay of cows in the herd. In the high-input dairy systems, however, culling policy is based mainly on unsatisfactory reproduction performance (Bagley, 1993).

In Ethiopia, crossbreeding of indigenous cattle breeds with the commonly known exotic dairy breeds was started in the early 1970s by the National Agricultural Research System (NARS) with various outcomes (Beyene, 1992; Kefena et al., 2006; Sendros, 2002). However, there is paucity of information on longevity traits and lifetime productivity of crossbred dairy cows. The objective of this study was, therefore, to evaluate longevity traits and provide baseline information on the lifetime milk and calf productivity of crossbred dairy cows with various levels of exotic gene inheritances in Ethiopia.

\section{MATERIALS AND METHODS}

\section{Data sources}

Data for this study was extracted from the dairy cattle crossbreeding experiment at Holetta Agricultural Research Centre (HARC), central Ethiopia. Holetta is located at $35 \mathrm{~km}$ west of Addis Ababa at $38.5^{\circ} \mathrm{E}$ longitude and $9.8^{\circ} \mathrm{N}$ latitude and elevation of 2400 $\mathrm{m}$ above sea level. The average annual rainfall is about $1200 \mathrm{~mm}$ and the average monthly relative humidity is $60.6 \%$.

Data used for this study were part of the national dairy cattle crossbreeding program that spanned over a period of 23 years from 1980 to 2003. Only cows that exit the herd due to voluntary culling such as reduced milk production, older age and involuntary culling such as accidents or health cases were considered. In either case, only cows that completed at least the first two lactations were included. This is because early culling of cows for other reasons, particularly for economic traits is regularly made at the first complete lactation or in the first three months of the second lactation. Lactation lengths of less than 60 milking days were also excluded from the final dataset based on the recommendation made by (Kiwuwa et al., 1983). Records of animals with abnormal calving such as abortions were considered as incomplete lactation and excluded from the final dataset. The data were not censored and we used actual data sets that were collected over the entire lifetime of crossbred dairy cows.

\section{Breeding plan and herd management}

In Ethiopia, dairy cattle genetic improvement program was started in the early 1970s. Initially, two imported exotic sire semen sources, namely Friesian $(F)$ and Jersey $(J)$ were used to cross with local Boran (Bo) dam to produce the first generation $\left(F_{1}\right)$ crossbred dairy calves. Secondly, $F_{1}$ bulls were selected based on dam milk yield and physical appearances to produce second generations $\left(F_{2}\right)$ crosses (Table 1). Thirdly, semen from pure exotic breeds was used to produce high-grade cows whose level of exotic gene further rose to $75 \%$.

All animals were subjected to almost similar feeding and management practices at the experiment station. They graze from 8:00 to $15: 00 \mathrm{~h}$ daily on natural pasture of the farm. Up on return to the barn, they were supplemented with conserved hay and green grass harvested from natural pasture or cultivated forages crops as available. In addition, milking cows were supplemented with nearly $2 \mathrm{~kg}$ local concentrate feeds per day constituting 30\% wheat bran, $31 \%$ wheat middling, $35 \%$ noug seed cake (Guizota absysinica), $3 \%$ bone and blood meal and $1 \%$ salt during milking. As the cows were kept for experimental purposes, culling procedures was less stringent and almost identical to the typical smallholder dairy production systems in Ethiopia (Table 1).

\section{Traits studied}

Traits studied and the specific definitions used in this particular study were as follows:

(a) Total life or longevity- period from birth to disposal from the herd;

(b) Herd life- period from the first calving to disposal from the herd;

(c) Productive life-number of days in milking during the entire lifetime;

(d) Lifetime milk yield- milk yield during the entire lifespan or longevity;

(e) Lifetime milk yield per day of total life;

(f) Lifetime milk yield per day of herd life;

(g) Lifetime milk yield per day of productive life;

(h) Parity or total number of lactation initiated (corresponds to lifetime calf crop) and;

(i) Age at first calving (AFC).

\section{Statistical model and data analysis}

A Generalized Linear Model (GLM) procedure of the statistical analysis system (SAS, 2004) package was used to analyze the 
Table 1. Mating design, genotype produced in the breeding program and number of cows considered in this study.

\begin{tabular}{|c|c|c|c|}
\hline Sire genotype & Dam genotype & Progeny produced & $\mathbf{N}$ \\
\hline $\mathrm{F}$ & Bo & $F_{1} \mathrm{FxBo}$ & 112 \\
\hline $\mathrm{J}$ & Bo & $F_{1} \mathrm{JxBo}$ & 106 \\
\hline $\mathrm{F}_{1} \mathrm{FBo}$ & $F_{1}$ FxBo & $\mathrm{F}_{2} \mathrm{FxBo}$ & 92 \\
\hline$F_{1}$ JBo & $\mathrm{F}_{1} \mathrm{~J} \times \mathrm{BO}$ & $\mathrm{F}_{2} \mathrm{~J} \times \mathrm{Bo}$ & 86 \\
\hline $\mathrm{F}$ & $\mathrm{F}_{1} \mathrm{FxBo}$ & 3/4F:1/4Bo & 69 \\
\hline $\mathrm{J}$ & $\mathrm{F}_{1} \mathrm{~J} \times \mathrm{Bo}$ & 3/4J:1/4Bo & 58 \\
\hline
\end{tabular}

$B o=$ Boran; $F=$ Friesian; $J=$ Jersey; $F_{1} F \times B o=F_{1}$ Friesian $x$ Boran; $F_{1} J \times B o$ $=F_{1}$ Jersey $x$ Boran; $F_{2} F x B o=F_{2}$ Friesian $x$ Boran; $F_{2} J \times B o=F_{2}$ Jersey $x$ Boran; 3/4F:1/4Bo $=75 \%$ Friesian inheritance; $3 / 4 \mathrm{~J}: 1 / 4 \mathrm{Bo}=75 \%$ Jersey inheritance.

data. The factor that was used as explanatory variable in the models were the six genetic group of cows ( $F_{1}$ FxBo, $F_{1} J \times B o, F_{2}$ $\mathrm{FxBo}, \mathrm{F}_{2} \mathrm{JxBo}, 75 \%$ Friesian and $75 \%$ Jersey inheritance). The dependent variables that include in the model include longevity, herd life, productive life, and lifetime milk yield, milk production per day of total life, milk yield per day of herd life, milk yield per day of productive life, calf crop and age at first calving (AFC). Generalized linear models used for lifetime traits analysis were:

$Y_{i j}=\mu+B_{j}+e_{i j}$

Where;

$Y_{i j}=$ lifetime traits estimates of $i^{\text {th }} \operatorname{cow}$ of $j^{\text {th }}$ genetic group;

$\mu=$ the overall mean;

$B_{j}=$ the effect of $j^{\text {th }}$ genetic group;

$\mathrm{e}_{\mathrm{ij}}=$ random error associated with $\mathrm{ij}^{\text {th }}$ cow and assumed to be normally and independently distributed (NID) $\left(0, \delta^{2}\right.$ e)

Moreover, ages at first calving (AFC) was also computed for each genetic group to observe its influence on the lifetime milk and calf crop production. AFC was estimated by fitting the data to fixed effects of linear model that consisted of genotype of the cow as follows:

$Y_{i j}=\mu+B_{i}+e_{i j}$

Where;

$Y_{i j}=$ Age at first calving of $i^{\text {th }}$ heifer of $j^{\text {th }}$ genetic group;

$\mu=$ the overall mean;

$B_{i}=$ the effect of $i^{\text {th }}$ genetic group;

$\mathrm{e}_{\mathrm{ij}}=$ the random error associated with $\mathrm{ij}^{\text {th }}$ observation and assumed to be normally and independently distributed (NID) $\left(0, \delta^{2}\right.$ ) .

\section{RESULTS}

\section{Longevity traits}

Brief results of least square means $\pm \mathrm{s}$. e. for various longevity traits, lifetime milk yield and calf crop produced by each genetic group as well as age at first calving are summarized in Table 2. The overall least squares means $\pm \mathrm{s}$. e. for the entire lifespan of various crossbred dairy cows was $4036 \pm 126.3$ days, (about 11 years). Statistically significant variation $(\mathrm{P}<0.05)$ were observed among different genotype for TL, HL and PL. The result under- scores the fact that there was a declining trend in total lifespan or longevity of dairy cows as the level of Friesian gene inheritances increased from 50 to $75 \%$. On the contrary, however, high-grade Jersey crossbred dairy cows had longer stayabilty in the herd, which was almost closer to $F_{1}$ Friesian crossbred dairy cows.

First generation Jersey $\left(F_{1}\right)$ crosses had significantly longer $\mathrm{HL}(\mathrm{P}<0.05)$ as compared to any crossbred genotypes considered in this study. Moreover, $F_{1} F \times$ Bo crosses and crosses with $75 \%$ Jersey inheritance had similar $\mathrm{HL}$ in the herd indicating their adaption to the lowinput low-output dairy production systems in the tropics. Significantly shortest $\mathrm{HL} \quad(\mathrm{P}<0.05)$ was observed in second generation $\left(\mathrm{F}_{2}\right)$ crosses and crosses with $75 \%$ Friesian inheritance (Table 2). $F_{2}$ JxBo crosses had about 248 days longer herd life than $F_{2}$ FxBo demonstrating that Jersey crosses are superior in all the longevity traits and stay longer in the herd as compared to Friesian crosses.

Likewise, $F_{1} \mathrm{~J} \times$ Bo crosses had significantly longer $(P<0.05)$ productive life followed by $F_{1}$ Frisian crossbred cows and crosses with $75 \%$ Jersey inheritances as compared to their contemporary genetic groups. On the other hand comparison between $F_{2}$ crosses showed that $F_{2}$ JxBo had about 120 days shorter PL than $F_{2}$ FxBo (Table 2) indicating the fact that Jersey crosses had shorter lactation length regardless of their relatively longer stayability in the herd. It is also important to note here that genetic groups with extended age at first calving had poorer lifetime performances as compared to early calving genetic groups (Table 2 ).

\section{Lifetime milk yield and calf crop production}

The overall LTMY for the entire crossbred groups and its distribution over different longevity traits is indicated in Table 2. Lifetime milk yield was highly influenced by cow's genotypes $(P<0.01)$. Similar to the longevity traits, the highest LTMY was observed in $F_{1}$ crosses with the highest LTMY in $F_{1}$ JxBo followed by $F_{1}$ FxBo and crosses with $75 \%$ of Friesian and Jersey inheritances. 
Table 2. Least squares means $\pm \mathrm{s}$. e. of longevity traits and lifetime milk and calf productivity of Boran crossbred cows in central Ethiopia.

\begin{tabular}{|c|c|c|c|c|c|c|c|}
\hline \multirow{2}{*}{ Lifetime traits } & \multirow{2}{*}{ Overall } & \multicolumn{6}{|c|}{ Genetic groups } \\
\hline & & $F_{1}$ FxBo & $F_{1}$ JxBo & $F_{2}$ FxBo & $F_{2} \mathrm{JxBO}$ & 3/4 F:1/4 Bo & 3/4J:1/4 Bo \\
\hline TL, days & $4036 \pm 126.3$ & $4200.3 \pm 135.1^{a}$ & $4269.8 \pm 135.1^{a}$ & $4021.4 \pm 179^{b}$ & $4036 \pm 157.0^{b}$ & $3721.9 \pm 270.3^{c}$ & $3970.3 \pm 237.4^{b}$ \\
\hline $\mathrm{HL}$, days & $2675.7 \pm 201.7$ & $2876.99 \pm 147.5^{b}$ & $3107.53 \pm 146.6^{a}$ & $2334.82 \pm 196.3^{d}$ & $2582.55 \pm 170.7^{\mathrm{c}}$ & $2435.32 \pm 291.4^{d}$ & $2717.29 \pm 257.8^{b}$ \\
\hline PL, days & $1951.8 \pm 173.9$ & $2145.47 \pm 127.1^{b}$ & $2387.33 \pm 126.4^{\mathrm{a}}$ & $1740.77 \pm 169.2^{c}$ & $1620.11 \pm 147.2^{d}$ & $1787.45 \pm 251.2^{c}$ & $2029.58 \pm 222.2^{b}$ \\
\hline LTMY,lit. & $10460.6 \pm 1117.4$ & $12816.7 \pm 817^{b}$ & $13546.50 \pm 812.3^{a}$ & $8565.8 \pm 1087.3^{d}$ & $6818.71 \pm 945.8^{\mathrm{e}}$ & $10929.54 \pm 1614^{c}$ & $10086.34 \pm 428^{c}$ \\
\hline LTMY/TL, lit & $2.56 \pm 0.2$ & $3.00 \pm 0.2^{a}$ & $3.04 \pm 0.2^{a}$ & $2.26 \pm 0.2^{c}$ & $1.65 \pm 0.2^{d}$ & $2.84 \pm 0.3^{\mathrm{ab}}$ & $2.54 \pm 0.3^{\mathrm{abc}}$ \\
\hline LTMY/HL,lit & $3.97 \pm 0.3$ & $4.61 \pm 0.2^{a}$ & $4.38 \pm 0.2^{\mathrm{a}}$ & $3.59 \pm 0.3^{b}$ & $2.64 \pm 0.3^{c}$ & $4.68 \pm 0.4^{a}$ & $3.89 \pm 0.4^{\mathrm{ab}}$ \\
\hline LTMY/PL,lit & $5.26 \pm 0.3$ & $5.77 \pm 0.2^{\mathrm{ab}}$ & $5.57 \pm 0.2^{\mathrm{ab}}$ & $4.86 \pm 0.3^{c}$ & $4.13 \pm 0.2^{d}$ & $6.16 \pm 0.4^{\mathrm{a}}$ & $5.07 \pm 0.3^{b c}$ \\
\hline Calf crop & $5.70 \pm 0.2$ & $6.25 \pm 0.1^{b}$ & $6.75 \pm 0.1^{a}$ & $5.32 \pm 0.2^{c}$ & $5.07 \pm 0.2^{d}$ & $4.41 \pm 0.3^{\mathrm{e}}$ & $6.37 \pm 0.2^{\mathrm{ab}}$ \\
\hline AFC, months & $43.21 \pm 0.9$ & $44.02 \pm 0.7^{b}$ & $38.8 \pm 0.6^{c}$ & $49.8 \pm 1.0^{\mathrm{a}}$ & $48.2 \pm 1.0^{\mathrm{a}}$ & $45.52 \pm 1.4^{b}$ & $39.72 \pm 1^{c}$ \\
\hline
\end{tabular}

$\mathrm{AFC}=$ age at first calving, $\mathrm{TL}=$ total life (longevity), $\mathrm{HL}=$ herd life, $\mathrm{PL}=$ productive life, $\mathrm{LTMY}=$ lifetime milk yield, $\mathrm{LTMY} / \mathrm{TL}=$ lifetime milk yield per day of total life, $\mathrm{LTMY} / \mathrm{HL}=$ lifetime milk yield per day of herd life, LTMY/PL= lifetime milk yield per day of productive life. Means with the same superscript in each row are not significantly different ( $p>0.05$ ).

The lowest LTMY was observed in second generation $\left(F_{2}\right)$ crosses. In all the traits investigated, first generation crosses particularly $F_{1}$ JxBo were superior in most of the desirable dairy traits. For instances, LTMY in $F_{1}$ JXBo exceeds LTMY in $F_{1}$ FxBo, $F_{2}$ FxBo and $F_{2} J \times B o$ by about $5.7,58.1$ and $98.7 \%$, respectively. Moreover, when LTMY distributed over the entire lifespan of the cows, $F_{1}$ crosses were more productive and dominant over all genetic groups whereas second generation crosses remained inferior. When LTMY is distributed over $\mathrm{HL}$ and $\mathrm{PL}$, the highest index was observed in $75 \%$ Friesian inheritance followed by $F_{1}$ crosses (Table 2). Yet, it is important to note that second generation crosses remained inferio when LTMY is distributed over HL and PL. Lifetime milk yield severely declined in $F_{2}$ crosses. For instances, reduction in LTMY from $\mathrm{F}_{1} \mathrm{JxBo}$ to $\mathrm{F}_{2} \mathrm{JxBo}$ was to the extent of $50 \%$. Similarly, decline in LTMY from $F_{1}$ FxBo to $F_{2}$ FxBo was up $33 \%$.

The overall calf crop produced for the entire herd was $5.7 \pm 0.2$ (Table 2). First generation crosses and crosses with $75 \%$ Jersey inheritance completed more number of lactations, i.e. produced more number of calf crops in their lifetime. However, the lowest number of lactation completed was recorded in $75 \%$ Friesian inheritance.

\section{DISCUSSION}

Evidences show that, for decades, selection in dairy cattle has dealt almost exclusively with production traits. Nowadays, traits like functional longevity are one of the increasingly growing concerns among dairy breeders because of its association with production costs (Arthur et al., 1992). Therefore, evaluation of some of the longevity and lifetime milk and calf crop productivity traits of crossbred dairy cattle with various levels of exotic inheritances would support producers make informed decisions to keep or cull dairy cows.

Literally, there are no sufficient and comprehensive research reports on the longevity and lifetime milk and calf crop productivity of crossbred dairy cows in Ethiopia. Available report shows that the mean disposal age in the present study is by far longer than the estimate reported in Enyew et al. (1999) for crossbred dairy cows in Ethiopia. They reported that the mean longevity of Arsi crossbred cows with 50,75 and $87.5 \%$ European inheritance was $6.02 \pm 0.4$ years. Interestingly, they also reported that there were no differences among the crossbred dairy cows with respect to the length of time they stayed in the herd, which is practically unrealistic. Such controversial results may be attributed to the way data was analyzed and sample size considered for each genetic groups. Decline in the lifespan of crossbred dairy cows in tropical climates with an increase in the level of exotic gene beyond $50 \%$ was reported in Vaccaro (1990). She noticed that under the Brazilian dairy crossbreeding experiment, there was a tendency of reduction in longevity traits as the level of exotic gene incorporation exceeds $50 \%$. Higher association between longer lifespan of dairy cows and number of lactations completed is useful to obtain more replacement heifers. Lower number of lactation completed in high-grade Frisian crossbred 
cows might be attributed to their relatively shorter lifespan in the herd. Several other studies (Kiwuwa et al., 1983) reported that high grade cows are characterized by longer calving interval that possibly extend inter-calving interval. Moreover, higher productivity per lactation with inadequacy of meeting the nutritional demand with large body size might have also contributed to the delayed resumption of reproductive activity, which cause delay in estrus and hence resulted in fewer numbers of calves produced or lactations completed in the lifetime of highgrade Friesian dairy cows.

Apparent variability in the length of $\mathrm{HL}$ among the crossbred dairy cows might be attributed to the noticeable differences in age at first calving. For instances, both Friesian and Jersey $\mathrm{F}_{2}$ crosses were characterized extended age at first calving that apparently reduces HL. Other reports (Sendros, 2002; Kefena et al., 2006) showed longer age at first calving, longer days open and longer calving interval in $\mathrm{F}_{2}$ crosses in Ethiopia. Longer $\mathrm{HL}$ in $\mathrm{F}_{1}$ crosses particularly in $F_{1}$ JxBo and crosses with $75 \%$ Jersey inheritance indicates that these genetic groups calve earlier, stay for longer period of time in the herd and completed more number of lactations. Moreover, it is an indication of the fact that Jersey crosses are taking the advantage of smaller body size in adapting to the prevailing environmental variables and, therefore, stayed in the herd for a longer period and avoid early culling. Almost similar patterns have been observed in the case of PL.

\section{Lifetime milk and calf productivity}

It is indisputable that lifetime milk yield and calf crop production in dairy cows depend on longevity traits, genotypes, management practices and other intrinsic and extrinsic factors. Overall, we noticed that Jersey crossbred dairy cows perform better in most lifetime traits, and in some cases similar to Friesian crosses. This indicates that Jersey crosses are an appropriate genotype for dairying, particularly under low-input low-output dairy production systems.

Higher LTMY observed in $F_{1}$ crosses particularly in $F_{1}$ JxBo, shows better efficiency of these genotypes for economic traits, longer stay in the herd and adaptation to the prevailing management practices. Moreover, $F_{1}$ crosses probably take the advantage of hybrid vigor that arises by crossing two genetically distant populations. Second-generation crosses suffer reduction in hybrid vigor by half than first generation crosses due to segregation and recombination losses (Falconer and Mackay, 1996; Majid et al., 1996; Syrstad, 1996; Cunningham and Syrstad, 1987; Sendros, 2002). Loss of hybrid vigor is the underpinning genetic factor for reduced performances in $\mathrm{F}_{2}$ crosses. Moreover, poor selection standards to select $F_{1}$ bulls for inter se mating may also greatly contributed free fall in the lifetime performances.

Decline in the overall productivity, particularly in LTMY was noticed as the level of Frisian genes increased beyond $50 \%$. This implies further incorporation Friesian gene might not be resulted in increased lifetime productivity unless the levels of management practices are simultaneously improved. The consistently better performance noticed in $F_{1}$ crosses of both Friesian and Jersey is consistent with several other reports. McDowell (1988b) revised crossbreeding results from 25 countries of the tropics involving 57 genetic groups, 15 native breeds and 7 European breeds and reported that $F_{1}$ crosses had considerable benefits. They calve earlier, yielded more milk (147\%), were milked for more days and had shorter calving interval. Other reports (Kiwuwa et al., 1983; Beyene, 1992; Kefena et al., 2006) agree well with the present results.

\section{Conclusion}

Brief overview and estimates of the traits considered in this study (longevity traits, lifetime milk and calf crop productivity) reveals that first generation crossbred dairy cows, particularly those crossed with Jersey semen outperforms their Friesian counterparts. Indeed, Friesian dairy breed is one of most popular dairy breed that outperforms Jersey under ideal production environments. However, higher performances of Jersey crosses underscore their adaptive capability to harsh environment, even with higher level of gene incorporation beyond $50 \%$. On the other hand, this reflects unmet management practices for high yielding Friesian crosses as well as susceptibility to some of the prevailing climatic variables. Drastic decline in lifetime performances of $F_{2}$ crosses reiterates continuous reduction in hybrid vigor and recombination losses in inter se mate $F_{1}$ populations. $F 2$ crosses are not appropriate genotype of choice for dairy production.

\section{ACKNOWLEDGEMENTS}

The authors are grateful to the Ethiopian Institute of Agricultural Research for fully sponsoring this study, and also grateful to $\mathrm{W} /$ ro Roman Hailesilasie for her careful data managements and retrieval from the main dairy database platform available at Holetta Agricultural Research Center.

\section{REFERENCES}

Arthur P F, Makarechian M, Beng RJ Weingardt R (1992). Longevity and lifetime productivity of cows in a purebred Hereford and two multibred systematic groups under range conditions. J. Dairy Sci. 71:1142-1147.

Bagley CP (1993). Nutritional management of replacement beef heifers: a review. J. Anim. Sci. 72: 3155-3163.

Beyene K (1992). Estimation of Additive and Non-Additive Genetic effects for Growth, Milk Yield and Reproduction Traits of Crossbred (Bos taurus $x$ Bos indicus) Cattle in the Wet and Dry Environments in Ethiopia. Ph.D. Dissertation, Cornell University, USA.

Brotherstone S, Verkamp RW, Hill G (1997). Genetic parameters for a 
simple predictor of the lifespan of Holstein-Friesian dairy cattle and its relationship to production. Anim. Sci. 65:31.

Chaudry MZ, Shafiq M (1995). Lifetime production performances of Holstein Friesian x Sahiwal crossbreds. Asian J. Anim. Sci. 8 (5): 499-503.

Cunningham EP, Syrstad O (1987). Crossbreeding Bos indicus and Bos taurus for milk production in the tropics. FAO Animal Production and Health Paper 68. Food and Agricultural Organization of the United Nations, Rome.

Enyew N, Brannang E, Rottmann OJ (1999). Reproductive performances and herd life of crossbred dairy cattle with different level of European inheritance in Ethiopia. In: Proceedings of $7^{\text {th }}$ Annual conference of Ethiopian Soc. Anim. Prod. (ESAP) held at Addis Ababa, Ethiopia, pp. 65-74.

Falconer DS, Mackay TFC (1996). Introduction to Quantitative Genetics. Longman, Harlow, England.

Ibeawuchi J A (1984). Longevity and milk production efficiency of Wadara (zebu) cattle in the semi-arid region of Nigeria. East Afr. Agric. J. 59 (1): 11-17.

Jairath L, Dekkers JCM, Schaeffer LR, Liu Z, Burnside EB, Kolstad B (1998). Genetic evaluation for herd life in Canada. J. Dairy Sci. 81: 550-562.

Kebreab E, Smith T, Tanner JC P., Osuji O (2005). Review of under nutrition in smallholder ruminant production systems in the tropics. In Ayantunde et al. (eds) Coping with feed scarcity in smallholder livestock systems in developing countries, Animal Science Group, Wageningen UR, Wageningen, The Netherlands, pp. 3-94.

Kefena E, Hegde BP, Tesfaye K (2006). Lifetime production and reproduction performances of Bos taurus $x$ Bos indicus crossbred cows in the central highlands of Ethiopia. Ethiopa J. Anim. Prod. 6 (2): 37-52.

Kiwuwa GH, Trail JCM, Kurtu MY, Getachew W, Anderson MF, Durkin J (1983). Crossbred dairy productivity in Arsi Region, Ethiopia. ILCA Research Report No. 11, ILCA, Addis Ababa.
Larroque H, Ducrocq V (2001). Relationship between type and longevity in the Holstein breed. Genet. Sel. Evo. 33:39-59.

Majid MA, Talukder A, Zahiruddin M (1996). Productive performance of pure breeds, $F_{1}, F_{2}$ and $F_{3}$ generations cows raised in Central Cattle Breeding and Dairy Farm of Bangladesh. Asian-Australian J. Anim. Sci. 9:461-464

McDowell RE (1988b). Strategies for genetic improvement of cattle in the warm climates. In: Second National Livestock Improvement Conference (NLIC) held at Addis Ababa, Ethiopia. pp. 24-26.

Renkema JA, Stelwagen J (1979). Economic evaluation of replacement rates in dairy herds. I. Reduction of replacement rates through improved health. Livest. Prod. Sci. 6: 15-27.

Rufino MC, Herrero M, Van Wijk MT, Hemerik L, De Ridder N, Giller KE (2009). Lifetime productivity of dairy cows in smallholder farming systems of the central highlands of Kenya. Animal 3 (7): 1044-1056.

SAS (Statistical Analysis System Institute) 2004. SAS guide for personal computers, version 6. SAS Institute, Kary, NC.USA.

Sendros D (2002). Genetic Factors Affecting Milk Production, Growth, and Reproductive Traits in Bos taurus $x$ Bos indicus Crosses in Ethiopia. PhD Thesis. Faculty of Natural and Agricultural Sciences, Department of Animal, Wildlife and Grassland Sciences. University of Free State, Bloemfontein, South Africa.

Syrstad O (1996). Dairy cattle crossbreeding in the tropics:Choice of crossbreeding strategies. Trop. Anim. Health Prod. 28:223-229.

Vaccaro LPDe (1990). Survival of European dairy breeds and their crosses with zebu in the tropics. Anim. Breed. Abs. 58: 476-494.

Zavadilova L, Nemcova E, Stipkova M, Bouska J (2009). Relationships between longevity and conformation traits in Czech Fleckvieh cows. Czech J. Anim. Sci. 54 (9):387-394. 